\title{
Supplementary Methods and Discussion
}

\section{S1. Kohler Mesa Site Description}

Measurements of nighttime nitrogen oxides have been made and previously reported at the NOAA Kohler mesa site. ${ }^{31-33}$ The site is located $150 \mathrm{~m}$ above and just west of the city of Boulder, which is part of the larger surrounding urban area of the Colorado Front Range cities, an area with some 4 million residents. Supplementary Figure 1 shows a map of the Front Range urban corridor indicating the location of the Kohler mesa site. Urban air pollution has been a longstanding issue in this area and has been the subject of numerous regional air quality studies, particularly in winter, when aerosol haze is a significant visibility and health issue. ${ }^{34-39}$ Measurements of aerosol composition during this study were consistent with those of the prior studies, showing ammonium nitrate to be the dominant fraction of fine mode aerosol in wintertime, with mass loadings on the order of several $\mu \mathrm{g} \mathrm{m}^{-3}$ during periods when the urban plume was present at the site. Thus, air masses sampled during this study appear to be characteristic of the wider urban region of the Colorado Front Range.

Supplementary Figure 2 shows the mean diurnal variation in potential temperature at the Kohler mesa site and at a nearby site on the Western edge of the city of Boulder, $150 \mathrm{~m}$ below. Potential temperature at Kohler mesa is the same as the urban area during the day, but is higher at night, indicating that the Kohler mesa site lies within the urban boundary layer during the day, but that urban emissions are likely less well mixed to the height of the mesa at night. Although there are episodes during which recent urban emissions are sampled at the site during the night (e.g., NO was periodically observed in the presence of excess ozone), in general, the site is impacted by emissions mixed to its height during the day that subsequently undergo chemical evolution overnight. Horizontal transport effects are still important and influence the temporal 
variation of nitrogen oxides, ozone, aerosol composition and $\mathrm{ClNO}_{2}$. Measured temporal variations are thus most likely to match 0 -D box model calculations for periods of very low wind speeds and thus slow horizontal transport.

\section{S2. Measurement Methods}

Gas phase chemical measurements included $\mathrm{CO}$ (VUV fluorescence), $\mathrm{O}_{3}$ (UV absorption), $\mathrm{NO}, \mathrm{NO}_{2}$ (diode laser cavity ring-down, d-CRDS), $\mathrm{NO}_{3}, \mathrm{~N}_{2} \mathrm{O}_{5}$ (pulsed cavity ringdown, p-CRDS) and $\mathrm{ClNO}_{2}$ (chemical ionization mass spectrometry, CIMS). The CIMS instrument also measured $\mathrm{N}_{2} \mathrm{O}_{5}$ and agreed well with the p-CRDS measurements, ${ }^{10}$ but the pCRDS measurements were used in the analysis reported here. Aerosol measurements included size distributions (ultra high sensitivity aerosol spectrometer, UHSAS), and chemical composition (particle into liquid sampler, PiLS, with ion chromatography analysis). Instruments were located in two adjacent trailers, and all gas phase and particle samples were taken from the top of a $9 \mathrm{~m}$ tower located between the two trailers. The CIMS and p-CRDS instruments for $\mathrm{NO}_{3}, \mathrm{~N}_{2} \mathrm{O}_{5}$ and $\mathrm{ClNO}_{2}$ shared a common inlet line (1/4" OD Teflon tubing) that split into two flows (2.5 SLPM to CIMS, 8 SLPM to p-CRDS) inside the instrument trailer. A port and valve system located at the top of the tower allowed for addition of NO or zero air to zero the p-CRDS and CIMS instruments and for standard addition of $\mathrm{N}_{2} \mathrm{O}_{5}$ in zero air for calibrations. The entire inlet system was mounted on a carriage with a manual crank that could be raised or lowered to allow for service of the inlet and regular exchanges of the Teflon inlet tubing, which were done approximately every 24 hours. Other gas phase instruments (e.g., $\mathrm{CO}, \mathrm{O}_{3}, \mathrm{NO}_{\mathrm{x}}$ ) sampled from individual, separate 1/4" Teflon inlet lines at the same height as the $\mathrm{NO}_{3} / \mathrm{N}_{2} \mathrm{O}_{5} / \mathrm{ClNO}_{2}$ inlet. The 
aerosol instruments sampled from a common inlet constructed of $3 / 4 "$ OD stainless steel, as described further below.

Meteorological data (temperature, pressure, relative humidity, wind speed and direction) were collected using standard instrumentation (Campbell Scientific) at the Kohler mesa from a separate $9 \mathrm{~m}$ tower located approximately $20 \mathrm{~m}$ from the trailers. In order to characterize the structure of the local boundary layer, particularly at night, meteorological data were also logged from additional existing stations: the NOAA David Skaggs Research Center, approximately 150 $\mathrm{m}$ below and $1 \mathrm{~km}$ East; and the National Center for Atmospheric Research Table Mesa facility, approximately $90 \mathrm{~m}$ above and $1.5 \mathrm{~km}$ south of the Kohler mesa site (see, e.g., Supplementary Figure 2).

\section{$\mathrm{ClNO}_{2}$ and $\mathrm{N}_{2} \mathrm{O}_{5}$ Detection by Chemical Ionization Mass Spectrometry}

$\mathrm{ClNO}_{2}$ and $\mathrm{N}_{2} \mathrm{O}_{5}$ were measured simultaneously by chemical ionization mass spectrometry using the sampling and detection scheme as outlined by Kercher et al. ${ }^{10}$ Ambient air was continuously sampled into the CIMS ionization region through a critical orifice (2.5 slpm) and ionized using the $\mathrm{I}^{-}$reagent ion. Ions then pass through a collisional dissociation region (CDC), where the electric field is tuned to optimize detection of anions via dissociative (high electric field) or associative (low electric field) charge transfer reactions. For this measurement, the $\mathrm{CDC}$ electric field was tuned low enough to preserve the associated anion clusters, $\mathrm{I}\left(\mathrm{ClNO}_{2}\right)^{-}$and $\left.\mathrm{I}_{2} \mathrm{~N}_{2} \mathrm{O}_{5}\right)^{-}$. After passing through an octupole ion guide, the ions enter the quadrupole mass spectrometer where they are mass selected and detected with an electron multiplier. 
Instrument calibrations were performed daily, and instrumental accuracy and precision were as described previously. ${ }^{10} \mathrm{~N}_{2} \mathrm{O}_{5}$ was added to the top of the sampling inlet such that mixing ratios from 1-5 ppbv were achieved in both ambient and zero air. The p-CRDS instrument measured the concentration of $\mathrm{N}_{2} \mathrm{O}_{5}$ being delivered through the sampling inlet. This concentration was used along with the CIMS count rate $(\mathrm{Hz})$ at the $\mathrm{I}\left(\mathrm{N}_{2} \mathrm{O}_{5}\right)^{-} \mathrm{m} / \mathrm{z}$ to determine a sensitivity for $\mathrm{N}_{2} \mathrm{O}_{5}$. After a stable $\mathrm{N}_{2} \mathrm{O}_{5}$ flow (in ambient and zero air) had developed, the sample air was passed over a deliquesced $\mathrm{NaCl}$ salt bed to generate $\mathrm{ClNO}_{2}$. With a yield of unity, ${ }^{8}$ the observed decrease in $\mathrm{N}_{2} \mathrm{O}_{5}$ was then used to determine the concentration of $\mathrm{ClNO}_{2}$ eluting from the salt bed reactor.

A potential artifact in the measurement of $\mathrm{ClNO}_{2}$ can arise through the reaction of ambient $\mathrm{N}_{2} \mathrm{O}_{5}$ on the inlet tubing walls, which might contain chloride deposited by aerosol particles or partitioning of $\mathrm{HCl}$. We routinely tested for such an artifact by monitoring the count rate at the $\left(\mathrm{ClNO}_{2}\right)^{-} \mathrm{m} / \mathrm{z}$ during standard additions of $\mathrm{N}_{2} \mathrm{O}_{5}$ to the sampling manifold. The $\mathrm{ClNO}_{2}$ produced during $\mathrm{N}_{2} \mathrm{O}_{5}$ additions was less than $2 \%$ of the added $\mathrm{N}_{2} \mathrm{O}_{5}$ on average, and often was not statistically different from our detection threshold. One such addition (morning of February $\left.14^{\text {th }}\right) \mathrm{N}_{2} \mathrm{O}_{5}$ led to $7 \%$ conversion of $\mathrm{N}_{2} \mathrm{O}_{5}$ to $\mathrm{ClNO}_{2}$. Correction of ambient $\mathrm{ClNO}_{2}$ observations for potential production in the sampling lines, based on $\mathrm{N}_{2} \mathrm{O}_{5}$ additions performed within 12 hours of any observation, did not affect the $\mathrm{ClNO}_{2}$ concentrations by more than the uncertainty of our measurements $\sim \pm 20 \% .^{10}$

Consistent with the above assessment are the detailed behaviors of $\mathrm{ClNO}_{2}$ and $\mathrm{N}_{2} \mathrm{O}_{5}$ relative to one another observed in ambient air. These two species were broadly correlated over the campaign (see Figure 2, main text), as expected since $\mathrm{N}_{2} \mathrm{O}_{5}$ is not likely to achieve steady state at this site during winter. ${ }^{31-33}$ However, their relationship changed significantly on short 
time scales, minutes-to-hours, demonstrating zero correlation or even anti-correlation (not shown) within a night. For example, on one such occasion shown in Supplementary Figure 3, $\mathrm{N}_{2} \mathrm{O}_{5}$ dropped from $\sim 500$ pptv to near zero, due to a local injection of NO, which chemically destroys $\mathrm{N}_{2} \mathrm{O}_{5}$ but not $\mathrm{ClNO}_{2} . \mathrm{N}_{2} \mathrm{O}_{5}$ is lost via thermal decomposition followed by reaction of $\mathrm{NO}_{3}$ with $\mathrm{NO}$ under such conditions. The $\mathrm{ClNO}_{2}$ signal detected by the CIMS was unaffected by the presence of NO, indicating that it was already present in the air mass and not produced by reaction of ambient $\mathrm{N}_{2} \mathrm{O}_{5}$ on the inlet surfaces. Moreover, on many mornings, $\mathrm{ClNO}_{2}$ was detected long after $\mathrm{N}_{2} \mathrm{O}_{5}$ had decayed away due to thermal decomposition and photochemical destruction of $\mathrm{NO}_{3}$. The $\mathrm{ClNO}_{2}$ photolysis lifetime is longer than the $\mathrm{N}_{2} \mathrm{O}_{5}$ thermal decomposition lifetime for this region during winter. These periods again demonstrate that the $\mathrm{ClNO}_{2}$ was present in ambient air and not significantly produced by $\mathrm{N}_{2} \mathrm{O}_{5}$ reactions on inlet surfaces.

\section{$\mathrm{NO}_{3}$ and $\mathrm{N}_{2} \mathrm{O}_{5}$ by pulsed Cavity Ringdown Spectroscopy}

Measurements of $\mathrm{NO}_{3}$ and $\mathrm{N}_{2} \mathrm{O}_{5}$ were made using a multi-channel, pulsed cavity ringdown spectrometer (p-CaRDS). Mixing ratios of $\mathrm{NO}_{3}$ were measured by optical absorption at $662 \mathrm{~nm}$. Mixing ratios of $\mathrm{N}_{2} \mathrm{O}_{5}$ were measured from the increase in the $\mathrm{NO}_{3}$ absorption signal at $662 \mathrm{~nm}$ following thermal conversion of $\mathrm{N}_{2} \mathrm{O}_{5}$ to $\mathrm{NO}_{3}$ in a heated channel. The $\mathrm{NO}_{3}$ and $\mathrm{N}_{2} \mathrm{O}_{5}$ channels were zeroed through the addition of nitric oxide (NO) at the tip of the inlet, which titrated $\mathrm{NO}_{3}$ to $\mathrm{NO}_{2}{ }^{40}$ Inlet transmission efficiencies for $\mathrm{NO}_{3}$ and $\mathrm{N}_{2} \mathrm{O}_{5}$ were calibrated by stoichiometric conversion in excess $\mathrm{NO}$ to $\mathrm{NO}_{2}$, which was measured separately in two 532-nm ring-down channels. ${ }^{41}$ The sampled air was filtered immediately before the absorption cells with 
PFA Teflon filters, which removed aerosols that would lead to optical extinction in the ringdown cells.

\section{$\mathrm{NO}$ and $\mathrm{NO}_{2}$ by diode laser Cavity Ringdown Spectroscopy}

Mixing ratios of $\mathrm{NO}$ and $\mathrm{NO}_{2}$ were made using a diode laser cavity ring-down spectrometer (d-CaRDS) based on optical extinction at $404 \mathrm{~nm} .{ }^{42} \mathrm{NO}_{2}$ was measured directly by optical extinction at this wavelength, while total $\mathrm{NO}_{\mathrm{x}}$ (and $\mathrm{NO}$ by difference) was measured in a second channel that converted $\mathrm{NO}$ to $\mathrm{NO}_{2}$ in excess $\mathrm{O}_{3}$. Both channels were zeroed by periodically overflowing the inlet with zero air.

\section{Aerosol Particle Size and Composition Measurements}

Aerosol were sampled through a stainless steel inlet at a height of $9 \mathrm{~m}$, and large particles were removed at the entrance into the trailer using a $1 \mu \mathrm{m}$ aerodynamic diameter impactor. Particles with diameters from 0.07 to $\sim 0.8 \mu \mathrm{m}$ were measured using a laser optical particle counter, ultra-high sensitivity aerosol spectrometer UHSAS. ${ }^{43}$ The measured size distributions were used to derive the sub-micrometer number, surface and volume of particles assuming a spherical particle shape. Particle diameters were corrected for hygroscopic growth between the higher temperature (lower $\mathrm{RH}$ ) inside the trailer compared to ambient air using a standard correction. ${ }^{44}$ Water-soluble aerosol chemical composition was measured using a particle-intoliquid sampler (PILS, Brechtel Mfg. Inc). ${ }^{45}$ Collected vials were analyzed by ion chromatography for the major inorganic anions and cations $\left(\mathrm{Na}^{+}, \mathrm{NH}_{4}^{+}, \mathrm{K}^{+}, \mathrm{Mg}^{+2}, \mathrm{Ca}^{+2}, \mathrm{Cl}^{-}\right.$, $\mathrm{NO}_{3}{ }^{-}$, and $\mathrm{SO}_{4}^{-2}$ ). Uncertainty in the ion chromatography analysis from calibrations is $+/-4 \%$ and $+/-7 \%$ for ammonium and anions (sulfate or nitrate), respectively. A subset of samples were analyzed more than one month later and showed that they took up additional ammonium. Since 
the particles were composed mainly of ammonium nitrate, the ratio of this additional ammonium to the original ammonium measurements $(28 \%)$ was used to correct all the other samples for a bias of ammonium evaporation. ${ }^{46}$ This correction brought the rest of the data set into ion balance within the measurement uncertainty, which is expected for tropospheric aerosols containing significant amounts of nitrate. ${ }^{17}$

The measured aerosol ionic composition was dominated by nitrate, ammonium, and sulfate. The measured fine-mode mass concentration when sampling the urban plume was typically $2-4 \mu \mathrm{g} \mathrm{m}^{-3}$. Nitrate usually accounted for more than half the measured mass, with ammonium and sulfate accounting for the majority of the remainder. Chloride was typically $1 \%$ by mass or less, and overall during the campaign, it correlated poorly with sodium $\left(\mathrm{R}^{2}<0.1\right)$. On a molar basis there was roughly three times as much aerosol chloride as sodium and, hence, the additional chloride was likely associated with ammonium.

PiLS samples were checked for evidence of contamination from local sources especially for the crucial measurement of particulate chloride. Contamination could have resulted from, for example, compounds such as $\mathrm{NaCl}$ or $\mathrm{MgCl}_{2}$ that are used locally in road salt. Chloride was above the PiLS detection limit most, but not all, of the time, while $\mathrm{Na}^{+}$was above the detection limit some of the time and $\mathrm{Mg}^{2+}$ was virtually always below the detection limit. Thus, if road salt was a local contaminant in the sampled air masses, $\mathrm{Na}$ and $\mathrm{Mg}$ in the aerosol would have been much higher than the detection limit. Since the PILS Na and Mg levels were quite low, aerosol chloride or $\mathrm{HCl}$ probably did not come from airborne road salt.

\section{S3. $\mathrm{CINO}_{2}$ in Boulder, $\mathrm{CO} 2008$}


Ambient measurements of $\mathrm{ClNO}_{2}$ were made February $26^{\text {th }}$ and $27^{\text {th }}, 2008$ in Boulder, $\mathrm{CO}$, as part of the integration for the ICEALOT 2008 field campaign. The data were taken at a location immediately adjacent to the David Skaags building of the NOAA Earth System Research Laboratory. No ancillary information was available for this time period, such as particle size and composition, $\mathrm{NO}_{\mathrm{x}}$, or $\mathrm{O}_{3}$, preventing a detailed analysis of this data. We show the time series for February $26^{\text {th }}, 2008$ in Supplementary Figure 4. The $\mathrm{ClNO}_{2}$ mixing ratio reached a maximum of $400 \mathrm{pptv}$ on February $26^{\text {th }}$, similar to the maximum mixing ratio observed on the Kohler Mesa during 2009. While limited, this 2008 data is additional support for our current findings of significant wintertime $\mathrm{ClNO}_{2}$ production at an inland location.

\section{S4. Aerosol Thermodynamic Modeling}

We used the online thermodynamic equilibrium Aerosol Inorganics Model (AIM) ${ }^{17}$ to calculate the particulate water, to infer aerosol $\mathrm{pH}$, and to assess the equilibrium partitioning of $\mathrm{HCl}$ for the given aerosol composition and meteorological conditions sampled in Boulder. We also used the ISOROPIAII model for comparison, ${ }^{47}$ and found similar results. Aerosol particles can exist as solid particles, metastable solutions free of solids, or as mixtures depending on the composition and humidity history experienced by the particles. ${ }^{48}$ The phase state (i.e. solid or liquid) of ambient aerosols remains uncertain. ${ }^{48}$ Here we assume, as is conventional in many atmospheric models, that the aerosol particles were metastable solutions, and so suppressed precipitation of commonly formed solids for most thermodynamic calculations. This assumption has implications for predictions of the $\mathrm{ClNO}_{2}$ yield as we describe in Section S6.

These thermodynamic calculations showed that, for metastable solutions composed of the charged balanced ammonium/nitrate/sulfate measured in Boulder, population average $\mathrm{pH}$ values 
ranged from $1-4$. The quoted $\mathrm{pH}$ range reflects the uncertainty stemming from the lack of contemporaneous $\mathrm{NH}_{3}$ and $\mathrm{HNO}_{3}$ measurements. However, the $\mathrm{pH}$ range is similar to other better constrained estimates for fine-mode particles made in other regions. ${ }^{20,49}$ Given the poor correlation with sodium and higher concentrations of chloride relative to sodium, we assume the dominant form of particulate chloride was via association with ammonium:

$$
\mathrm{NH}_{3(g)}+\mathrm{HCl}_{(g)} \rightleftarrows \mathrm{NH}_{4(a q)}^{+}+\mathrm{Cl}_{(a q)}^{-}
$$

SR1 can be considered a summary of an overall larger reaction system in which the actual partitioning of $\mathrm{HCl}$ between the gas and particulate phase will depend on the availability of $\mathrm{NH}_{3}$, $\mathrm{HNO}_{3}$, and $\mathrm{H}_{2} \mathrm{SO}_{4}$, among others.

Using the AIM model, ${ }^{17}$ we performed a batch of parametric runs, systematically varying the $\mathrm{pH}$ of the condensed phase and calculating the resulting equilibrium ratio of $\mathrm{HCl}_{(\mathrm{g})} / \mathrm{Cl}_{(\mathrm{aq})}^{-}$for ammonium-nitrate-sulfate particles. The $\mathrm{pH}$-dependent $\mathrm{HCl}_{(\mathrm{g})} / \mathrm{Cl}^{-}(\mathrm{aq})$ unit-less ratio ranges from $>35$ down to $\sim 2$ for $\mathrm{pH} 1-4$. From the measured particulate chloride, we would then infer $\mathrm{HCl}$ mixing ratios were $50-750 \mathrm{ppt}$ during the Boulder study. If the particles instead consisted of crystalline $\mathrm{NH}_{4} \mathrm{NO}_{3}(\mathrm{~s})$ and $\mathrm{NH}_{4} \mathrm{Cl}(\mathrm{s})$, the $\mathrm{HCl}$ vapor pressure in equilibrium with the solid at $298.15 \mathrm{~K}$ is a factor of 1.8 higher than that for $\mathrm{HNO}_{3},{ }^{17}$ and thus the $\mathrm{HCl}$ mixing ratio would be $1.8 \mathrm{x}$ higher than that of $\mathrm{HNO}_{3}$. The latter typically ranges from $50 \mathrm{pptv}$ to $>1 \mathrm{ppb}$ in rural and urban locations. ${ }^{50-52}$ We conclude from these calculations that there was likely sufficient gasphase $\mathrm{HCl}$ to provide enough total chloride for the observed $\mathrm{ClNO}_{2}$ production.

\section{S5. 0-D Chemical Box Model with dynamic particulate chloride and HCl Reservoir}

A 0-D time-dependent chemical box model was developed to interpret the observed $\mathrm{ClNO}_{2}$ and particulate chloride mixing ratios. The model is similar in concept to that described in 
Osthoff et al., ${ }^{5}$ however we include a dynamic particulate chloride, and an $\mathrm{HCl}$ gas-phase reservoir which is assumed to be in equilibrium with particulate chloride.

The model evolves freely through the night from initial conditions set by sunset observations of $\mathrm{NO}, \mathrm{NO}_{2}, \mathrm{O}_{3}$, particle surface area and volume concentrations, particulate chloride $\left(p \mathrm{Cl}^{-}\right)$, and $\mathrm{RH}$. We determine the initial chemical conditions that best explain the observed $\mathrm{NO}_{2}, \mathrm{O}_{3}, \mathrm{ClNO}_{2}, \mathrm{~N}_{2} \mathrm{O}_{5}$ concentrations at any given time. We assume $\mathrm{N}_{2} \mathrm{O}_{5}$ and $\mathrm{ClNO}_{2}$ are initially zero at sunset, and that the initial $\mathrm{HCl}_{(\mathrm{g})}$ is given by the equilibrium with the observed particulate chloride. We adjust aerosol $\mathrm{pH}$, to typically between 2.3 and 4, and then hold $\mathrm{pH}$ constant during a model run. For our box modeling purposes, aerosol $\mathrm{pH}$ is simply a tuning parameter used to generate the total chloride needed to match the observed $\mathrm{ClNO}_{2}$ and particulate chloride evolution.

The model integrates the rate equations for the chemical reactions shown in Supplementary Table 1 and conserves total chlorine throughout the integration: $\mathrm{Cl}_{\text {Total }}=\mathrm{HCl}+$ $p \mathrm{Cl}^{-}+\mathrm{ClNO}_{2}$. Rate constants for reactions SR2-4 are taken from Sander, et al. ${ }^{53}$ For reaction SR5, we assume an $\mathrm{NO}_{3}$ lifetime of $\sim 20$ minutes, consistent with values inferred from previous observations. ${ }^{27}$ However, $\mathrm{NO}_{3}$ reactivity typically played a minor role given the high $\mathrm{NO}_{2}(>5$ ppb) and cold temperatures $(<278 \mathrm{~K})$ characteristic of this data set. The branching between R1a and $\mathrm{R} 1 \mathrm{~b}$, i.e. the $\mathrm{ClNO}_{2}$ yield, $\phi_{C l N O 2}$, is determined by finding that which best matches the observed $\mathrm{ClNO}_{2}$. Values for $\phi_{C I N O 2}$ ranged from $0.07-0.36$ with a mean of 0.18 for all the air masses studied over the campaign. We then compare this value to that predicted from laboratory parameterizations of known chemistry ${ }^{8}$ and measured aerosol composition (see Section S5).

The reaction probability for $\mathrm{N}_{2} \mathrm{O}_{5}, \gamma\left(\mathrm{N}_{2} \mathrm{O}_{5}\right)$, is an adjustable parameter used to bring the modeled $\mathrm{O}_{3}, \mathrm{NO}_{2}$, and $\mathrm{N}_{2} \mathrm{O}_{5}$ into agreement with the observations. Values of $\gamma\left(\mathrm{N}_{2} \mathrm{O}_{5}\right)$ between 
$0.005-0.03$ are used, consistent with expectations based on a recent parameterization described by Bertram and Thornton ${ }^{54}$ that depends on particle liquid water content, nitrate, and chloride. The choice of $\gamma\left(\mathrm{N}_{2} \mathrm{O}_{5}\right)$ affects our inferred $\mathrm{ClNO}_{2}$ yield estimates, but $\gamma\left(\mathrm{N}_{2} \mathrm{O}_{5}\right)$ is relatively well constrained by requiring the model to match observed $\mathrm{O}_{3}, \mathrm{NO}_{2}$, and $\mathrm{N}_{2} \mathrm{O}_{5}$ in air masses clearly unaffected by fresh $\mathrm{NO}_{\mathrm{x}}$ emissions or strong land surface interactions (see below).

We have neglected super-micron particles and fogs or clouds as $\mathrm{N}_{2} \mathrm{O}_{5}$ sinks or direct sources of $\mathrm{ClNO}_{2}$. Typically, fine-mode particles dominate particle surface area. However, on some of the nights with high RH (> 80\%) fogs were visually observed during this campaign. Given their high surface area, fogs would represent a large $\mathrm{N}_{2} \mathrm{O}_{5} \operatorname{sink}^{55}$ unaccounted for in our model. However, the transport patterns characteristic of the site are such that higher RH is often associated with sampling the urban boundary layer. Under such conditions there is thus a greater potential for sampling relatively fresh nighttime $\mathrm{NO}_{\mathrm{x}}$ emissions, which can titrate $\mathrm{N}_{2} \mathrm{O}_{5}$, and which in turn makes a box model initialized at sunset less valid. In general, such unaccounted for additional losses, overestimated interaction times, or mixing of air masses with different emission time histories, cause our model to underestimate the $\mathrm{ClNO}_{2}$ yield on fine-mode aerosol particles.

These transport related issues are evident in Supplementary Figure 5, which shows $\mathrm{O}_{3}$, $\mathrm{NO}_{2}, \mathrm{~N}_{2} \mathrm{O}_{5}$, and $\mathrm{ClNO}_{2}$ observations and model predictions for the night of February $22^{\text {nd }}-23^{\text {rd }}$. During a more quiescent period from $\sim 1-6$ hours past midnight, the model generally captures well the evolution of $\mathrm{O}_{3}, \mathrm{NO}_{2}, \mathrm{~N}_{2} \mathrm{O}_{5}$. The model slightly underestimates $\mathrm{ClNO}_{2}$ until 4-6 hours past sunset, which was the period chosen to match all observations. A constant nitryl chloride yield of $18 \%$ thus likely underestimates the true yield early in the night, but adequately reproduces $\mathrm{ClNO}_{2}$ growth through the rest of the night even during what are clearly fresh 
(nighttime) injections of $\mathrm{NO}_{\mathrm{x}}$ sampled at the site between 8 and 12 hours past sunset. A model initialized at sunset will not be able to reproduce the observed titration of ozone and $\mathrm{N}_{2} \mathrm{O}_{5}$, nor the large increase in $\mathrm{NO}_{2}$ during such events. As noted above, however, such fresh $\mathrm{NO}_{\mathrm{x}}$ injections should not affect $\mathrm{ClNO}_{2}$ already in an air mass.

\section{S6. $\mathrm{CINO}_{2}$ Yield Parameterizations as a function of $\mathrm{RH}$ and Particulate $\mathrm{Cl}^{-}$Mass Fraction}

In the currently accepted mechanism for $\mathrm{N}_{2} \mathrm{O}_{5}$ reactions on aqueous solutions, the instantaneous branching between $\mathrm{HNO}_{3}$ formation (R1a) and $\mathrm{ClNO}_{2}$ production (R1b) is determined by the competition between liquid water, $\mathrm{H}_{2} \mathrm{O}_{(1)}$, and chloride for the electron deficient intermediate presumed to be similar to solvated $\mathrm{NO}_{2}{ }^{+}$(shown as $\mathrm{H}_{2} \mathrm{ONO}_{2}{ }^{+}$).

$$
\begin{aligned}
& \mathrm{N}_{2} \mathrm{O}_{5(g)} \rightarrow \mathrm{N}_{2} \mathrm{O}_{5(a q)} \\
& \mathrm{N}_{2} \mathrm{O}_{5(a q)}+\mathrm{H}_{2} \mathrm{O} \rightleftharpoons \mathrm{H}_{2} \mathrm{ONO}_{2(a q)}^{+}+\mathrm{NO}_{3(a q)}^{-} \\
& \mathrm{H}_{2} \mathrm{ONO}_{2(a q)}^{+}+\mathrm{Cl}_{(a q)}^{-} \stackrel{k_{c}}{\longrightarrow} \mathrm{ClNO}_{2}+\mathrm{H}_{2} \mathrm{O} \\
& \mathrm{H}_{2} \mathrm{ONO}_{2(a q)}^{+}+\mathrm{H}_{2} \mathrm{O} \stackrel{k_{d}}{\longrightarrow} \mathrm{HNO}_{3}+\mathrm{H}_{3} \mathrm{O}^{+}
\end{aligned}
$$

Based on this mechanism and laboratory measurements of the branching between SR6c and SR6d, the instantaneous $\mathrm{ClNO}_{2}$ yield $\left(\phi_{\mathrm{ClNO}_{2}}\right)$ can be estimated as

$$
\phi_{\mathrm{ClNO}_{2}}=\frac{k_{c}\left[\mathrm{NO}_{2}^{+}\right]\left[\mathrm{Cl}^{-}\right]}{k_{c}\left[\mathrm{NO}_{2}^{+}\right]\left[\mathrm{Cl}^{-}\right]+k_{d}\left[\mathrm{NO}_{2}\right]\left[\mathrm{H}_{2} \mathrm{O}\right]}=\frac{1}{1+\frac{k_{d}\left[\mathrm{H}_{2} \mathrm{O}\right]}{k_{c}\left[\mathrm{Cl}^{-}\right]}}
$$

where laboratory studies infer the ratio of $\mathrm{k}_{\mathrm{d}} / \mathrm{k}_{\mathrm{c}}$ to be $1 / 450-1 / 890{ }^{8,}{ }^{18}$ Herein, we use the more recent $1 / 450$ which leads to lower yields for the same $\left[\mathrm{H}_{2} \mathrm{O}\right] /\left[\mathrm{Cl}^{-}\right]$than the previous estimate. Calculating $\phi_{\mathrm{CINO} 2}$ thus requires knowledge of the particle liquid water content, which is a function of ambient relative humidity $(\mathrm{RH})$ and composition, and the particulate chloride 
concentration. Assuming the chloride mass fraction is constant across the particle surface area distribution simplifies the calculation in that only the mole ratio of $\mathrm{H}_{2} \mathrm{O}$ to $\mathrm{Cl}^{-}$is then needed. Below we describe how $\phi_{C I N O 2}$ can be estimated under this simplifying assumption using a thermodynamic model, RH, and aerosol composition.

We used the $\mathrm{AIM}^{17}$ model to explore $\phi_{\mathrm{CINO}}$ across a range of $\mathrm{RH}$ and chloride mass loadings. The AIM model provides a calculated aerosol water content given relative humidity (RH) and aerosol composition as inputs. For these calculations, we chose as the dominant particle component either ammonium sulfate (AS), when working with the IMPROVE network data, or ammonium nitrate (AN) when working with our Boulder 2009 data. No significant differences were found in terms of the $\mathrm{ClNO}_{2}$ yield by using these two different substrates. We assume organic matter acts like ammonium sulfate or nitrate because we use the total gravimetric fine-mode dry mass to calculate the chloride mole fraction. The impacts of this assumption are discussed below. We varied the particle chloride dry mass mole fractions from $<1 \times 10^{-5}$ to 0.25 while keeping the $\mathrm{RH}$ constant. $\mathrm{NH}_{4}{ }^{+}$was increased with $\mathrm{Cl}^{-}$in order to maintain overall charge balance. All potential solid precipitates were suppressed. The $\phi_{C I N O 2}$ was then calculated for each $\mathrm{Cl}^{-}$value based on the particle water content reported by AIM. The same procedure was repeated for different $\mathrm{RH}$, ranging from $10 \%$ to $90 \%$.

In order to facilitate rapid, online calculation of $\phi_{\mathrm{CINO}}$, for use in box modeling and for extrapolations with the IMPROVE network data, we parameterized $\phi_{\text {CINO2 }}$ to be a function of RH and the particulate chloride mass fraction $\left(\mathrm{MF}_{\mathrm{Cl}^{-}}\right)$with the form:

$$
\phi_{\mathrm{ClNO}_{2}}=\frac{1}{1+\left(\frac{Y_{f i t}}{M F_{\mathrm{Cl}^{-}}}\right)}
$$




$$
Y_{\text {fit }}=\sum a_{n} R H^{n}
$$

which resembles the original yield expression. $Y_{\text {fit }}$ is a polynomial fit which incorporates the AIM predicted particle water content as a function of $\mathrm{RH}$ and the ratio of the two rate constants, $\mathrm{k}_{1}$ and $\mathrm{k}_{2} . Y_{\text {fit }}$, as shown in equation SE3, is obtained by fitting individual $\phi_{C I N O 2} \mathrm{Vs} . M_{\mathrm{Cl}^{-}}$curves obtained for different RH values to equation SE2. A different fitting parameter is obtained for each $\mathrm{RH}$, and the resulting $\mathrm{RH}-$ dependent parameters can then be fit to equation SE3. Supplementary Figure 6 shows the $\phi_{C I N O 2}$ Vs. $M F_{C^{-}}$curve over a range of different RH.

The major assumptions when employing this parameterization are that, (1) the aerosol particles are aqueous solution droplets with the hygroscopicity of AS or AN, and (2) the particle chloride mass fraction is constant across the surface-area distribution of the particle population. We expect the first assumption leads to underestimates of $\phi_{C I N O 2}$, though not necessarily $P_{C I N O 2}$, while the second assumption leads to overestimates of $\phi_{\text {CINO2. }}$ Field measurements tend to show that the water content of ambient particles in the polluted boundary layer increases with $\mathrm{RH}$, but usually not substantially more than pure AS particles between RH 30 - 90\%; while particle phase remains highly uncertain. ${ }^{48,56}$ Thus, if particles are less hygroscopic than AS or AN, or are crystalline solids, then we overestimate liquid water content, which in turn causes an underestimate of the competition of reaction SR6c with SR6d (i.e. $\mathrm{CINO}_{2}$ formation). ${ }^{7}{ }^{57}$ It should also be noted that recent experiments show that $\mathrm{ClNO}_{2}$ is produced from surface reactions of $\mathrm{N}_{2} \mathrm{O}_{5}$ with $\mathrm{HCl}^{58}$ Our assumption of constant chloride mass fraction across the size distribution likely overestimates $\phi_{C I N O 2}$ on a population average, because if the chloride is confined to a small fraction of the surface area, then only a small fraction of $\mathrm{N}_{2} \mathrm{O}_{5}$ reactions will result in $\mathrm{ClNO}_{2}$ production. There is too little data on this question at present to allow a more 
refined approach to calculating $\phi_{\text {CINO2 }}$ from network observations of particulate chloride. Thus, we rely on the Boulder observations as well as those made in the Long Island Sound ${ }^{10}$ and the Gulf of Mexico ${ }^{5}$ to provide additional constraints.

\section{S7. Seasonal $P_{\mathrm{CINO} 2}$ Estimates from Equation 1 in Main Text}

Assuming $\mathrm{NO}_{\mathrm{x}}$ is in steady-state, the local mass flux of $\mathrm{NO}_{\mathrm{x}}$ through $\mathrm{N}_{2} \mathrm{O}_{5}$ heterogeneous chemistry can be determined by the product of the $\mathrm{NO}_{\mathrm{x}}$ emission rate and the fraction of the $\mathrm{NO}_{\mathrm{x}}$ loss rate caused by $\mathrm{N}_{2} \mathrm{O}_{5}$ chemistry. Annual $\mathrm{NO}_{\mathrm{x}}$ emissions $\left(E_{N O x}\right)$ with $1 \times 1^{\circ}$ resolution were obtained from the EDGAR global emissions database. United States $\mathrm{NO}_{\mathrm{x}}$ emissions $\left(E_{N O x}\right)$ were reflective of the year 2000 and reported in $\mathrm{kg} \mathrm{NO}$ per year, which we converted to moles of nitrogen per year. For seasonal calculations, we simply divide the annual values from the EDGAR database by 4 . The seasonal cycle in total U.S. $\mathrm{NO}_{\mathrm{x}}$ emissions is small, but a more refined approach could adjust for seasonal variations at the regional scale. ${ }^{59}$

The fraction of $\mathrm{NO}_{\mathrm{x}}$ oxidized to nitrate by $\mathrm{N}_{2} \mathrm{O}_{5}$ chemistry $\left(f_{\mathrm{N} 2 \mathrm{O} 5}\right)$ was obtained from the 0-2 km output of the GEOS-Chem chemical transport model run for the year $2005{ }^{13}$ and projected onto a $1^{\circ} \times 1^{\circ}$ grid. The model uses a recent $\mathrm{N}_{2} \mathrm{O}_{5}$ reaction probability parameterization developed by Evans and Jacob $^{60}$ which includes different reaction probabilities for different particle types and RH and temperature dependences based on available experimental data. Seasonal values of $f_{\mathrm{N} 2 \mathrm{O} 5}$, which range from 0 to 1 , are shown in Supplementary Figure 9. Significant seasonal cycles in $\mathrm{OH}$ production, temperature, and $\mathrm{RH}$ lead to strong seasonality in the predicted $f_{\mathrm{N} 2 \mathrm{O} 5}$. Maximum values are during the winter months, when the lower temperatures push the $\mathrm{N}_{2} \mathrm{O}_{5} / \mathrm{NO}_{3}$ equilibrium toward $\mathrm{N}_{2} \mathrm{O}_{5}$ and reduce the importance of $\mathrm{NO}_{3}$ reactions with 
biogenic hydrocarbons, and in areas of high $\mathrm{NO}_{\mathrm{x}}$ emissions such as the Northeastern United States. The annual mean $f_{N 2 O 5}$ averaged over the continental U.S. is 0.38 .

As pointed out in the main text, our $P_{C I N O 2}$ estimates depend on the extent to which the GEOS-Chem model accurately reflects $f_{N 2 O 5}$. While detailed field studies have indicated a larger variability in the $\mathrm{N}_{2} \mathrm{O}_{5}$ reaction probability than predicted by model parameterizations, ${ }^{26,}{ }^{27}$ the most important quantity for the analysis presented here is $f_{N 2 O 5}$. We provide a cursory comparison of $\mathrm{f}_{\mathrm{N} 2 \mathrm{O} 5}$ predicted by GEOS-Chem to that quantity inferred from our Boulder observations. The accuracy of such a comparison is limited mainly by the lack of an $\mathrm{OH}$ measurement coincident with our observations. The detailed box modeling of our data suggests $~$ $30-60 \%$ of $\mathrm{NO}_{\mathrm{x}}$ available at sunset reacts via $\mathrm{N}_{2} \mathrm{O}_{5}$ to $\mathrm{HNO}_{3}$ or $\mathrm{ClNO}_{2}$ over the course of a night. Wintertime measurements of $\mathrm{OH}$ concentrations elsewhere in North America ${ }^{61}$ suggest daily maximum values of $1 \times 10^{6}$ molec $\mathrm{cm}^{-3}$ and at times reaching $2 \times 10^{6}$ molec $\mathrm{cm}^{-3}$. Taking $\mathrm{OH}$ to be $1 \times 10^{6}$ molec $\mathrm{cm}^{-3}$ for the entire daylight period in Boulder during February, we estimate that $\sim 30 \%$ of $\mathrm{NO}_{\mathrm{x}}$ available at sunrise would be converted to $\mathrm{HNO}_{3}$. These estimates in turn suggest $f_{\mathrm{N} 205} \sim 0.6$ (i.e. $0.45 /[0.45+0.30]$ ) for the Boulder area during wintertime, which is similar to the wintertime mean value of $\sim 0.5$ predicted by GEOS-Chem for the same region (see Supplementary Figure 9, panel A).

\section{S7.1 $\mathrm{ClNO}_{2}$ Yield Estimates from Aerosol and Precipitation Composition Databases}

Our goal is to provide estimates of $\phi_{\mathrm{CINO} 2}$ that are consistent with all available $\mathrm{ClNO}_{2}$ observations and that faithfully reconstruct the likely spatial variation in the availability of chloride, i.e. increasing towards the coasts. We use a combination of the IMPROVE network ${ }^{23}$ 
measurements of the fine mode chloride mass fraction and our parameterization of the $\mathrm{ClNO}_{2}$ yield ( $\phi_{\mathrm{CINO} 2}$ in equation SE3) together with the wet deposition data of chloride and nitrate provided by the National Atmospheric Deposition Program (NADP). ${ }^{22}$ From each of these two data sets, we created gridded fields of approximations to $\phi_{\text {CINO2 }}$.

The $\mathrm{ClNO}_{2}$ yield estimates for the U.S. were based, in part, on aerosol chloride data from the Interagency Monitoring of PROtected Visual Environments (IMPROVE). ${ }^{23}$ Dry, fine mode total and chloride mass concentrations $\left(\mu \mathrm{g} / \mathrm{m}^{3}\right)$, reported as a 24-hour average every three days for each IMPROVE site, were used from the period covering January 2001 to December 2008. We routinely updated our calculations with the most recent version of data from this period, i.e. up to that available as of January 2010, but there were never discernable changes in our predictions as a result. This 8 -year period was chosen because the data is relatively recent, and there is a noticeable improvement in particulate chloride detection limits occurring in data reported after 2000. But, negative chloride values still exist in the data set in certain regions, especially between 2001 and 2003. We treat these values as arising from statistical fluctuations about a measurement of zero, and thus include them in the averaging. The median chloride mass fraction values for each site over the 7-year period were assumed to represent the typical annual or seasonal average and were gridded to $1^{\circ} \times 1^{\circ}$ over the contiguous United States. Standard deviations were on the order of the medians indicating high inter-annual variability. The differences between using means or medians were negligible.

We input the IMPROVE fine-mode chloride mass fraction data into equation SE3, assuming $80 \% \mathrm{RH}$ in every grid cell to produce $\phi_{\mathrm{ClNO}_{2}}^{\mathrm{IMP}}$. The higher RH is meant to produce accurate yields near the coast where there is sufficient chloride. We take this quantity as the average instantaneous branching between R1a and R1b (see main text). Use of $\phi_{\mathrm{CINO}_{2}}^{\mathrm{IMP}}$ alone in 
equation E1, without adjustments to match yields inferred from observations would imply that $\mathrm{ClNO}_{2}$ production is only limited by the competition between SR6c and SR6d and $\mathrm{NO}_{\mathrm{x}}$ abundance, and not by chloride availability either in total or in terms of its distribution across the particle size distribution. Hence, estimates based on IMPROVE data alone and the above equations significantly over predict the yields for the Boulder grid cell, likely due to these limitations. Thus, we use the NADP precipitation composition data to place a limit on the total amount of soluble chloride that could be converted into $\mathrm{ClNO}_{2}$ by nighttime $\mathrm{N}_{2} \mathrm{O}_{5}$ chemistry.

Towards this end, relatively recent NADP data was chosen in order for estimates to more accurately represent current conditions and to avoid using data prior to the implementation of improved sampling designs that minimize ion artifacts. ${ }^{22}$ NADP reports total wet deposition of nitrate and chloride in $\mathrm{kg} / \mathrm{ha}$ for each site on a seasonal basis. Assuming that essentially all $\mathrm{NO}_{\mathrm{x}}$ emissions are converted to $\mathrm{HNO}_{3}$ or particulate $\mathrm{NO}_{3}{ }^{-}$and deposited by either dry or wet deposition, and that all inorganic chlorine $(\mathrm{HCl}+$ particulate $)$ is similarly lost to deposition, then the ratio of chloride to nitrate measured in precipitation should then equal the ratio of these species in the atmospheric column from which they precipitated. The fraction of the nitrate attributable to nighttime oxidation of $\mathrm{NO}_{\mathrm{x}}$ through $\mathrm{N}_{2} \mathrm{O}_{5}$ for each site location can be calculated by scaling the measured nitrate by the appropriate $f_{N 2 O 5}$. We then derive an estimate of the chloride availability for $\mathrm{CINO}_{2}$ production $\phi_{\mathrm{CINO}_{2}}^{\mathrm{NADP}}$ from the mole ratio of chloride to nitrate measured contemporaneously in precipitation.

$$
\phi_{\mathrm{CINO}_{2}}^{\mathrm{NADP}}=\frac{\mathrm{mol}_{\mathrm{Cl}^{-}}}{f_{\mathrm{N}_{2} \mathrm{O}_{5}} \mathrm{~mol}_{\mathrm{NO}_{3}^{-}}} \quad \mathrm{SE} 4
$$

The $\phi_{\mathrm{CINO}_{2}}^{\mathrm{NADP}}$ values carry the seasonal dependence in $f_{\mathrm{N} 2 \mathrm{O5}}$ (see below), in addition to any seasonal dependence in the deposition patterns, and represent an upper-limit to the potential $\mathrm{ClNO}_{2}$ yield 
as we assume that all chloride in precipitation is in a form that can be converted into $\mathrm{ClNO}_{2}$ by $\mathrm{N}_{2} \mathrm{O}_{5}$.

The seasonal mean $\phi_{\mathrm{CINO}_{2}}^{\mathrm{NADP}}$ of each site was taken as representative for that site. Standard deviations were typically about half of the mean. However, sites near the coast, or near large $\mathrm{NO}_{\mathrm{x}}$ emissions, did exhibit standard deviations slightly larger than the mean values. Thus, we expect significant year-to-year variability in chloride availability. The resulting site-specific $\phi_{\mathrm{CINO}_{2}}^{\mathrm{NADP}}$ values were then gridded to $1^{\mathrm{o}} \mathrm{x} 1^{\mathrm{o}}$ over the contiguous United States.

For use in equation E1, we then created $\phi_{\mathrm{ClNO}_{2}}$ fields, where, for each grid cell, we used the lesser of the two quantities, $\phi_{\mathrm{CINO}_{2}}^{\mathrm{IMP}}$ or $\phi_{\mathrm{CINO}_{2}}^{\mathrm{NADP}^{2}}$. For comparison, in Supplementary Figure 7, we show the annual mean fields of $\phi_{\mathrm{CINO}_{2}}^{\mathrm{IMP}}$ and $\phi_{\mathrm{CINO}_{2}}^{\mathrm{NADP}}$. We infer from this figure that the central and north-central U.S. exhibits high chloride mass fractions, but low total chloride relative to the fraction of $\mathrm{NO}_{\mathrm{x}}$ that reacts as $\mathrm{N}_{2} \mathrm{O}_{5}$. Seasonal fields of $\phi_{\mathrm{CINO} 2}$ from the melding of $\phi_{\mathrm{CINO}_{2}}^{\mathrm{IMP}}$ and $\phi_{\mathrm{CINO}_{2}}^{\mathrm{NADP}_{2}}$ are shown in Supplementary Figure 8. This combined approach produces a wintertime mean $\phi_{C I N O 2}$ of $17 \%$ in the grid cell containing Boulder, $\mathrm{CO}$ which is in very good agreement with the mean value of $18 \%$ inferred from our $\mathrm{ClNO}_{2}$ observations. In addition, the $\phi_{\mathrm{CINO} 2}$ are in agreement with the values constrained by the limited set of coastal $\mathrm{ClNO}_{2}$ observations. ${ }^{5,10}$

\section{S7.2 Seasonal $P_{\mathrm{CINO}}$ Values}

As outlined in the main text, our estimate of the annual total $P_{C I N O 2}$ of $3.6 \mathrm{Tg} \mathrm{Cl} \mathrm{yr}^{-1}$ is the sum of seasonal average values determined by equation E1 and the quantities shown in Figures 4A and S6 - S7. In Supplementary Figure 10, we show the seasonal components of $P_{\text {CINO2, }}$ $P_{\mathrm{ClNO}_{2}}^{s}$, where the superscript $s$ denotes season: winter (a), spring (b), summer (c), fall (d). The 
corresponding values of $P_{\mathrm{CINO}_{2}}^{s}$, i.e. the spatial integral of the fields shown in Supplementary Figure 10a-d, are 1.35, 0.89, 0.45, $0.89 \mathrm{Tg} \mathrm{Cl}$, respectively.

As noted above, this approach likely produces an upper-limit to $P_{\mathrm{CINO} 2}$ as we implicitly assume that all available chloride can be converted into $\mathrm{ClNO}_{2}$ by $\mathrm{N}_{2} \mathrm{O}_{5}$. However, we can't rule out that the actual value may be close to this limit, particularly in regions where chloride is probably a limiting reagent, as evidenced by the good agreement between the $\phi_{C I N O 2}$ predicted for the Boulder region and that derived from our $\mathrm{ClNO}_{2}$ observations (see preceding section). As we point out in the main manuscript, under certain conditions, this upper end likely provides a challenge to our current understanding of reactive nitrogen closure, namely: at the end of a night above the wintertime nocturnal surface layer in high $\mathrm{NO}_{\mathrm{x}}$ regions. We are unaware of reactive nitrogen closure studies under such conditions necessary to provide tests of this prediction. Since $\mathrm{ClNO}_{2}$ recycles $\mathrm{NO}_{\mathrm{x}}$ within the first few hours after sunrise, $\mathrm{ClNO}_{2}$ almost always represents a negligible fraction of reactive nitrogen during the day.

\section{S8. Alternative Methods for Estimating $\boldsymbol{P}_{\mathrm{CINO} 2}$}

We used the available data sets to generate additional estimates of the $\mathrm{ClNO}_{2}$ source across the U.S. It is rather straightforward to determine fairly robust upper limits. Determining meaningful lower limits is admittedly more difficult.

Using Eqn 1 in the main text as a basis, but altering the nitryl chloride yields used in that equation provides additional insights into the possible magnitude of $P_{\text {CINO2 }}$. For example, if we use only the $\phi_{\mathrm{CINO}_{2}}^{\mathrm{IMP}}$, assuming $50 \% \mathrm{RH}$ across the nighttime U.S., we calculate $P_{\mathrm{CINO} 2}$ is $5.7 \mathrm{Tg} \mathrm{Cl}$ $\mathrm{yr}^{-1}$. As noted above, this determination implicitly assumes $\mathrm{ClNO}_{2}$ production is unlimited by the availability of total chlorine, and is thus an upper limit. Similarly, if we use $\phi_{\mathrm{CINO}_{2}}^{\mathrm{NADP}}$ after setting 


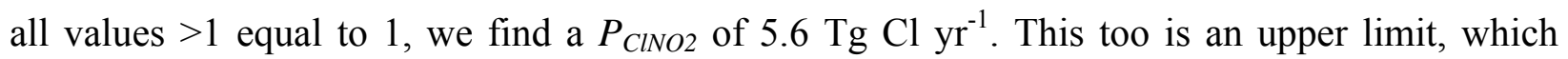
although it accounts for the total amount of chloride available in a given region, it assumes all of it can be converted into $\mathrm{ClNO}_{2}$ without regard to its partitioning to aerosol particles.

The IMPROVE based yields are most directly related to the chemistry which leads to $\mathrm{ClNO}_{2}$ formation and thus, we can also further refine these in concert with available $\mathrm{ClNO}_{2}$ observations to develop an alternate range in $P_{C I N O 2}$. Our box modeling of the Boulder 2009 $\mathrm{ClNO}_{2}$ observations showed that, on average, the yield predicted from SE 2 was a factor of 4 higher than that necessary to match the $\mathrm{ClNO}_{2}$ concentration, as expected based on the assumptions made to simplify the calculation and to address the lack of size-resolved particulate chloride observations across the U.S. Consistent with these findings, when we use only the IMPROVE chloride data and an $\mathrm{RH}$ of $50 \%$, the $\phi_{\mathrm{CINO}_{2}}^{\mathrm{s}}$ values predicted from SE 2 for the Boulder region during winter are $4 \mathrm{x}$ larger than suggested by our $\mathrm{ClNO}_{2}$ observations. Interestingly, the $\phi_{\mathrm{CINO} 2}$ values predicted for coastal regions are at most $50 \%$ greater than the yields determined from analyses of actual $\mathrm{ClNO}_{2}$ observations in those regions. ${ }^{5}$ Thus, dividing all yields by 4 would probably underestimate $\mathrm{ClNO}_{2}$ production in coastal regions, where a significant fraction of $\mathrm{ClNO}_{2}$ production occurs, while dividing all yields by 1.5 would likely overestimate inland $\mathrm{ClNO}_{2}$ production. These considerations thus suggest U.S. $P_{C I N O 2}$ ranges from 1.4 to almost certainly less than $5.6 \mathrm{Tg} \mathrm{Cl} \mathrm{yr}^{-1}$. 


\section{Supplementary Notes and References}

31. Brown, S. S. et al. Nitrogen oxides in the nocturnal boundary layer: Simultaneous in situ measurements of $\mathrm{NO}_{3}, \mathrm{~N}_{2} \mathrm{O}_{5}, \mathrm{NO}_{2}$, NO, and $\mathrm{O}_{3}$. Journal Of Geophysical ResearchAtmospheres 108, D94299 (2003).

32. Brown, S. S., Stark, H. \& Ravishankara, A. R. Applicability of the steady state approximation to the interpretation of atmospheric observations of $\mathrm{NO}_{3}$ and $\mathrm{N}_{2} \mathrm{O}_{5}$. Journal Of Geophysical Research-Atmospheres 108, D174539 (2003).

33. Brown, S. S., Stark, H., Ciciora, S. J. \& Ravishankara, A. R. In-situ measurement of atmospheric $\mathrm{NO}_{3}$ and $\mathrm{N}_{2} \mathrm{O}_{5}$ via cavity ring-down spectroscopy. Geophysical Research Letters 28, 3227-3230 (2001).

34. Levin, E. J. T. et al. Aerosol physical, chemical and optical properties during the Rocky Mountain Airborne Nitrogen and Sulfur study. Atmospheric Environment 43, 1932-1939 (2009).

35. Neff, W. D. The Denver Brown Cloud studies from the perspective of model assessment needs and the role of meteorology. Journal Of The Air \& Waste Management Association 47, 269-285 (1997).

36. Lewis, C. W., Baumgardner, R. E., Stevens, R. K. \& Russwurm, G. M. Receptor Modeling Study Of Denver Winter Haze. Environmental Science \& Technology 20, 1126-1136 (1986).

37. Haagenson, P. L. Meteorological And Climatological Factors Affecting Denver AirQuality. Atmospheric Environment 13, 79-85 (1979). 
38. Richards, L. W., Sloane, C. S., Watson, J. G. \& Chow, J. C., in Visibility and Fine Particles, ed. Mathai, C. V., p. 394-409. Air \& Waste Management Association, Pittsburg, PA, 1990.

39. Burns, S., Frey, S. J., Chow, J. C., Watson, J. G. \& Sloane, C. S., in Visibility and Fine Particles, ed. Mathai, C. V., p. 363-373. Air \& Waste Management Association, Pittsburg, PA, 1990.

40. Dube, W. P. et al. Aircraft Instrument for Simultaneous, in situ Measurement of $\mathrm{NO}_{3}$ and $\mathrm{N}_{2} \mathrm{O}_{5}$ via Pulsed Cavity Ring-Down Spectroscopy. Review Of Scientific Instruments 77 (2006).

41. Fuchs, H., Dube, W. P., Cicioira, S. J. \& Brown, S. S. Determination of Inlet Transmission and Conversion Efficiencies for in situ Measurements of the Nocturnal Nitrogen Oxides, $\mathrm{NO}_{3}, \mathrm{~N}_{2} \mathrm{O}_{5}$ and $\mathrm{NO}_{2}$, via Pulsed Cavity Ring-Down Spectroscopy. Analytical Chemistry 80, 6010-6017 (2008).

42. Fuchs, H., Dube, W. P. \& Brown, S. S. A sensitive and versatile detector for atmospheric $\mathrm{NO}_{2}$ and $\mathrm{NO}_{\mathrm{x}}$ basd on blue diode laser cavity ring-down spectroscopy. Environmental Science \& Technology 10.1021/es902067h (2009).

43. Cai, Y., Montague, D. C., Mooiweer-Bryan, W. \& Deshler, T. Performance characteristics of the ultra high sensitivity aerosol spectrometer for particles between 55 and 800 nm: Laboratory and field studies. Journal Of Aerosol Science 39, 759-769 (2008).

44. Nenes, A., Pandis, S. N. \& Pilinis, C. ISORROPIA: A new thermodynamic equilibrium model for multiphase multicomponent inorganic aerosols. Aquatic Geochemistry 4, 123152 (1998). 
45. Orsini, D. A. et al. Refinements to the particle-into-liquid sampler (PILS) for ground and airborne measurements of water soluble aerosol composition. Atmospheric Environment 37, 1243-1259 (2003).

46. Sorooshian, A. et al. Modeling and characterization of a particle-into-liquid sampler (PILS). Aerosol Science And Technology 40, 396-409 (2006).

47. Fountoukis, C. \& Nenes, A. ISORROPIA II: a computationally efficient thermodynamic equilibrium model for $\mathrm{K}^{+}-\mathrm{Ca}^{2+}-\mathrm{Mg}^{2+}-\mathrm{NH}_{4}{ }^{+-} \mathrm{Na}^{+}-\mathrm{SO}_{4}{ }^{2-}-\mathrm{NO}_{3}{ }^{-}-\mathrm{Cl}^{-}-\mathrm{H}_{2} \mathrm{O}$ aerosols Atmos. Chem. Phys. 7, 4639 (2007).

48. Martin, S. T. Phase transitions of aqueous atmospheric particles. Chemical Reviews 100, 3403-3453 (2000).

49. Pathak, R. K., Louie, P. K. K. \& Chan, C. K. Characteristics of aerosol acidity in Hong kong. Atmospheric Environment 38, 2965-2974 (2004).

50. Parrish, D. D. et al. Total Reactive Oxidized Nitrogen Levels And The Partitioning Between Individual Species At 6 Rural Sites In Eastern North-America. Journal Of Geophysical Research-Atmospheres 98, 2927-2939 (1993).

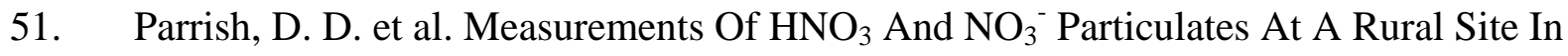
The Colorado Mountains. Journal Of Geophysical Research-Atmospheres 91, 5379-5393 (1986).

52. Zhang, L. et al. Measurements of reactive oxidized nitrogen at eight Canadian rural sites. Atmospheric Environment 42, 8065 (2008).

53. Chemical Kinetics and Photochemical Data for Use in Stratospheric Modeling, Evaluation Number 15 2006, NASA Jet Propulsion Laboratory, California Institute of Technology, Pasadena, California 
54. Bertram, T. H. \& Thornton, J. A. Towards a general parameterization of $\mathrm{N}_{2} \mathrm{O}_{5}$ reactivity: the competing effects of particle liquid water, nitrate, and chloride. Atmospheric Chemistry and Physics in press (2009).

55. Osthoff, H. D. et al. Observation of Daytime $\mathrm{N}_{2} \mathrm{O}_{5}$ in the Marine Boundary Layer during New England Air Quality Study - Intercontinental Transport and Chemical Transformation 2004. Journal Of Geophysical Research-Atmospheres 111, - (2006).

56. Dick, W. D., Saxena, P. \& McMurry, P. H. Estimation of water uptake by organic compounds in submicron aerosols measured during the Southeastern Aerosol and Visibility Study. Journal Of Geophysical Research-Atmospheres 105, 1471-1479 (2000).

57. Thornton, J. A. \& Abbatt, J. P. D. $\mathrm{N}_{2} \mathrm{O}_{5}$ Reaction on Submicron Sea Salt Aerosol: Kinetics, Products, and the Effect of Surface Active Organics. Journal Of Physical Chemistry A 109, 10004-10012 (2005).

58. Raff, J. D. et al. Chlorine activation indoors and outdoors via surface-mediated reactions of nitrogen oxides with hydrogen chloride. Proceedings of the National Academy of Sciences 106, 13647-13654 (2009).

59. Jaeglé, L., Steinberger, L., Martin, R. V. \& Chance, K. Global partitioning of $\mathrm{NO}_{\mathrm{x}}$ sources using satellite observations: Relative roles of fossil fuel combustion, biomass burning and soil emissions. Faraday Discussions 130, 407 - 423 (2005).

60. Evans, M. J. \& Jacob, D. J. Impact of new Laboratory Studies of $\mathrm{N}_{2} \mathrm{O}_{5}$ Hydrolysis on Global Model Budgets of Tropospheric Nitrogen Oxides, Ozone, and OH. Geophysical Research Letters 32 (2005). 
61. Cai, C. X. et al. Performance evaluation of an air quality forecast modeling system for a summer and winter season - Photochemical oxidants and their precursors. Atmospheric Environment 42, 8585-8599 (2008). 


\section{Supplementary Figures and Legends}

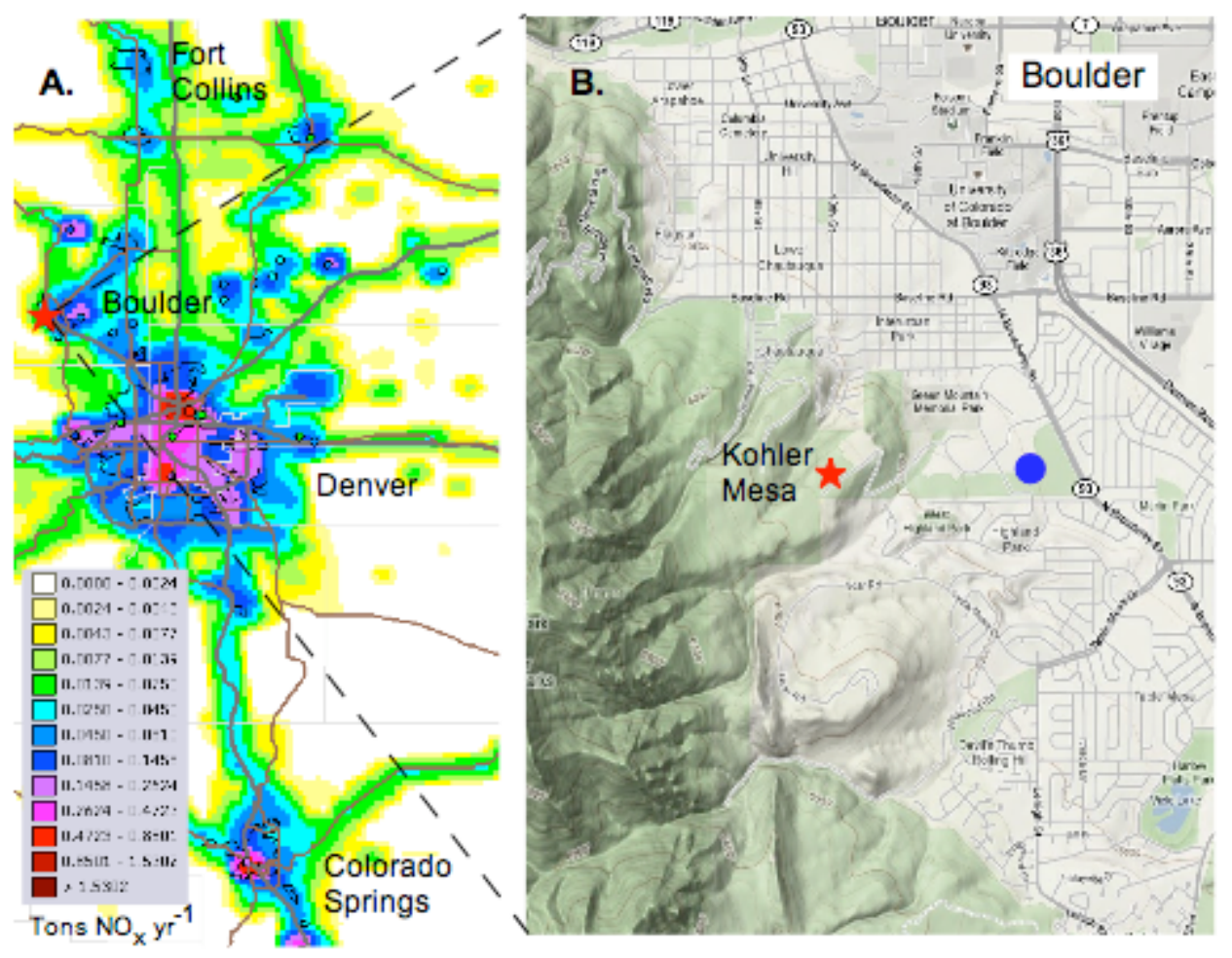

Supplementary Figure 1: A. Map of the Colorado front range urban corridor, color-coded by $\mathrm{NO}_{\mathrm{x}}$ emissions (EPA 1999 National Emissions Inventory). B. Expanded view of the city of Boulder, Colorado, showing terrain features. The red star in both maps marks the location of Kohler mesa. The blue circle in (B) marks the location of the reference temperature measurement in the Boulder urban area (see Figure S2). 


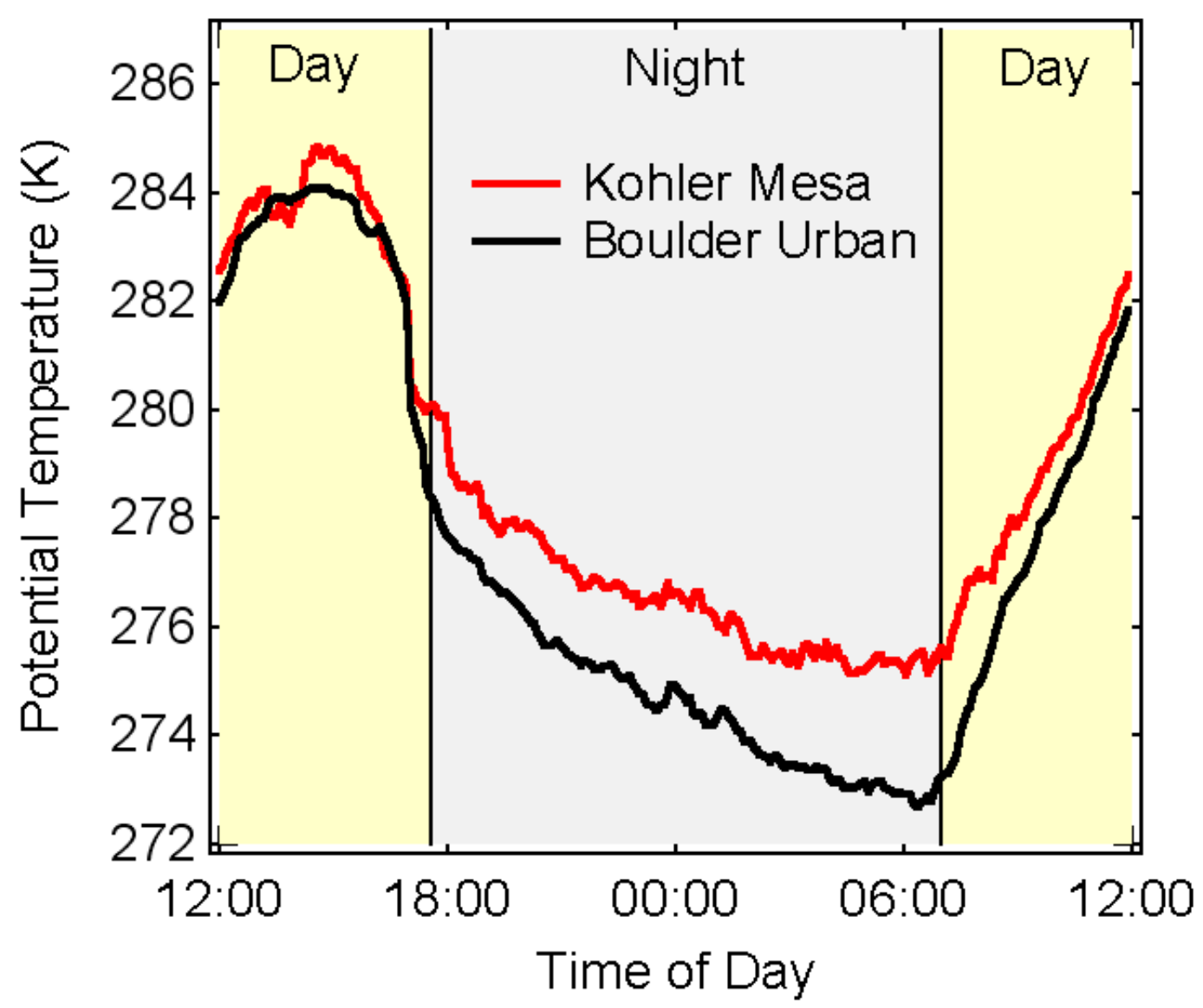

Supplementary Figure 2: Average diurnal variation of potential temperature (K), referenced to surface level pressure at the Kohler mesa and in the nearby Boulder urban area (see Figure S1) during February 2009. 

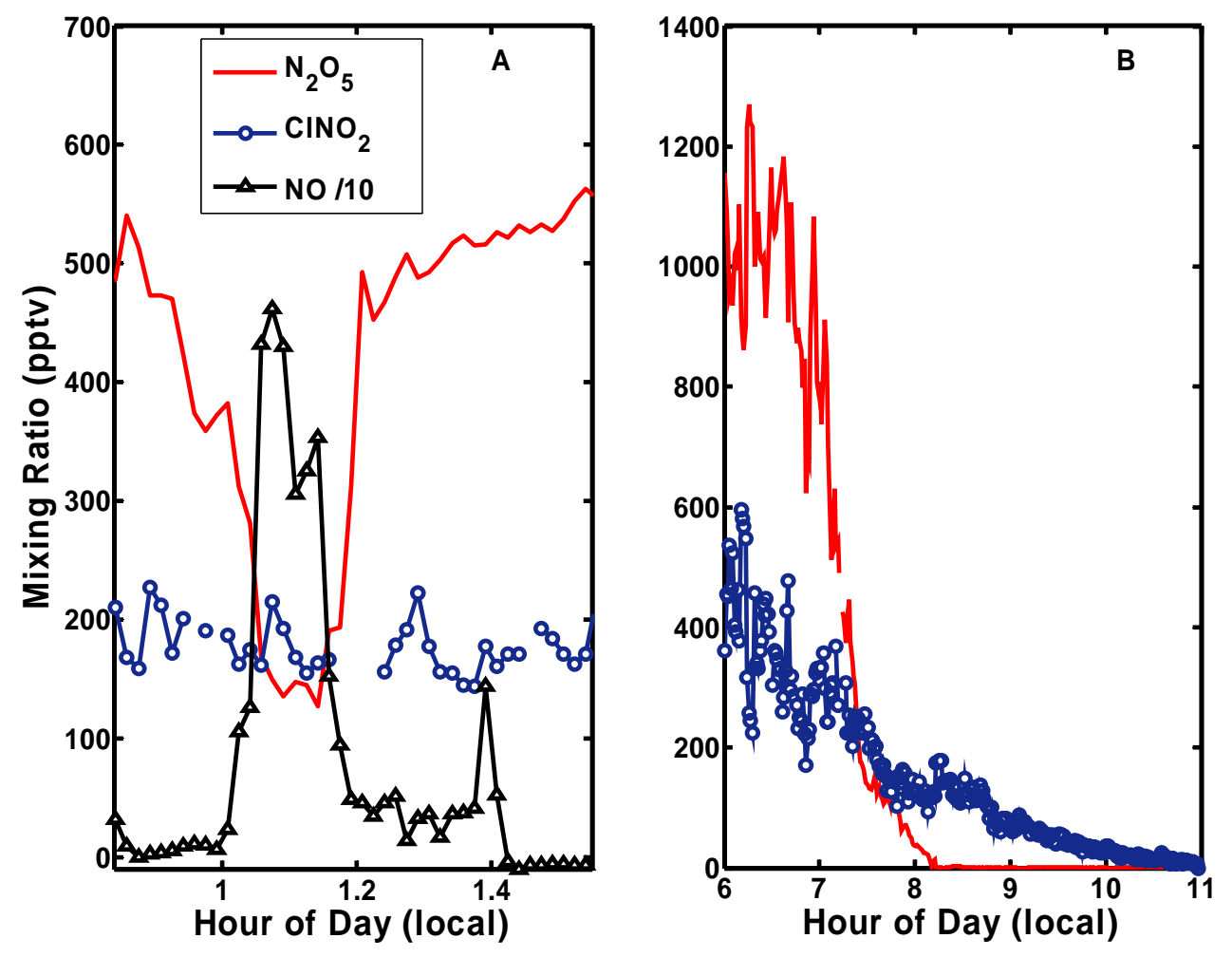

Supplementary Figure 3: Detailed behaviors of $\mathrm{N}_{2} \mathrm{O}_{5}$ and $\mathrm{CINO}_{2}$ in ambient air. In panel A, $\mathrm{N}_{2} \mathrm{O}_{5}, \mathrm{ClNO}_{2}$, and NO mixing ratios are shown for a 1-hour period on February $16^{\text {th }}$ in which a clear titration of $\mathrm{N}_{2} \mathrm{O}_{5}$ by $\mathrm{NO}$ reaction with $\mathrm{NO}_{3}$ was observed. $\mathrm{N}_{2} \mathrm{O}_{5}$ drops from 500 ppt down to 150 pptv with little to no change in the observed $\mathrm{ClNO}_{2}$. In panel $\mathbf{B}, \mathrm{N}_{2} \mathrm{O}_{5}$ and $\mathrm{ClNO}_{2}$ mixing ratios on the morning of February $16^{\text {th }}$ are shown. After sunrise ( 6:50 AM), $\mathrm{N}_{2} \mathrm{O}_{5}$ decays rapidly, while $\mathrm{ClNO}_{2}$ decays much more slowly, staying at values between 100 - 150 pptv even though $\mathrm{N}_{2} \mathrm{O}_{5}$ is near zero. The observed behavior is a convolution of photochemistry and transport. 


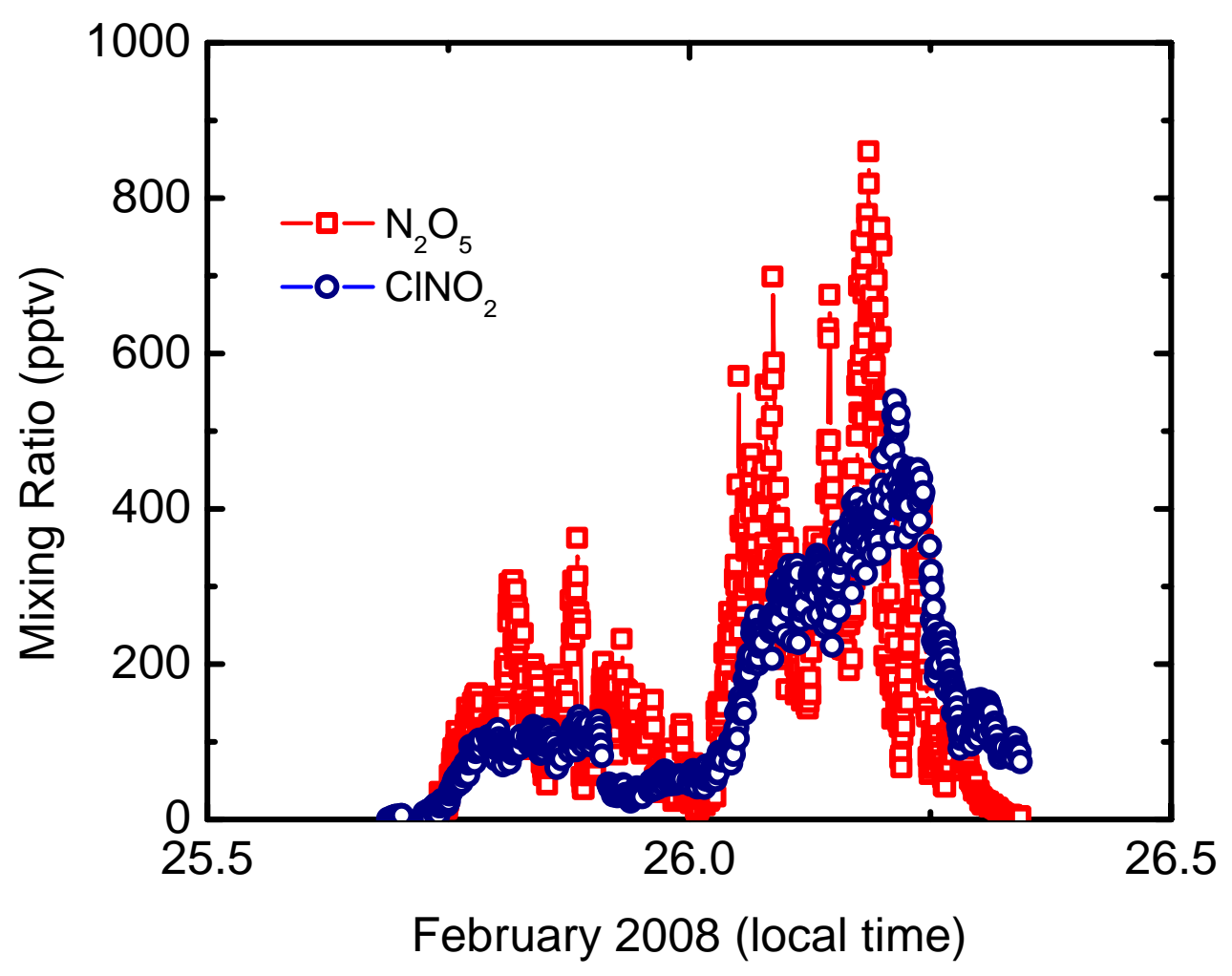

Supplementary Figure 4: February 2008 Observations. Time series of $\mathrm{N}_{2} \mathrm{O}_{5}$ (red squares) and $\mathrm{ClNO}_{2}$ (blue circles) mixing ratios measured the night of February $26^{\text {th }}$, 2008 from Boulder, CO. 

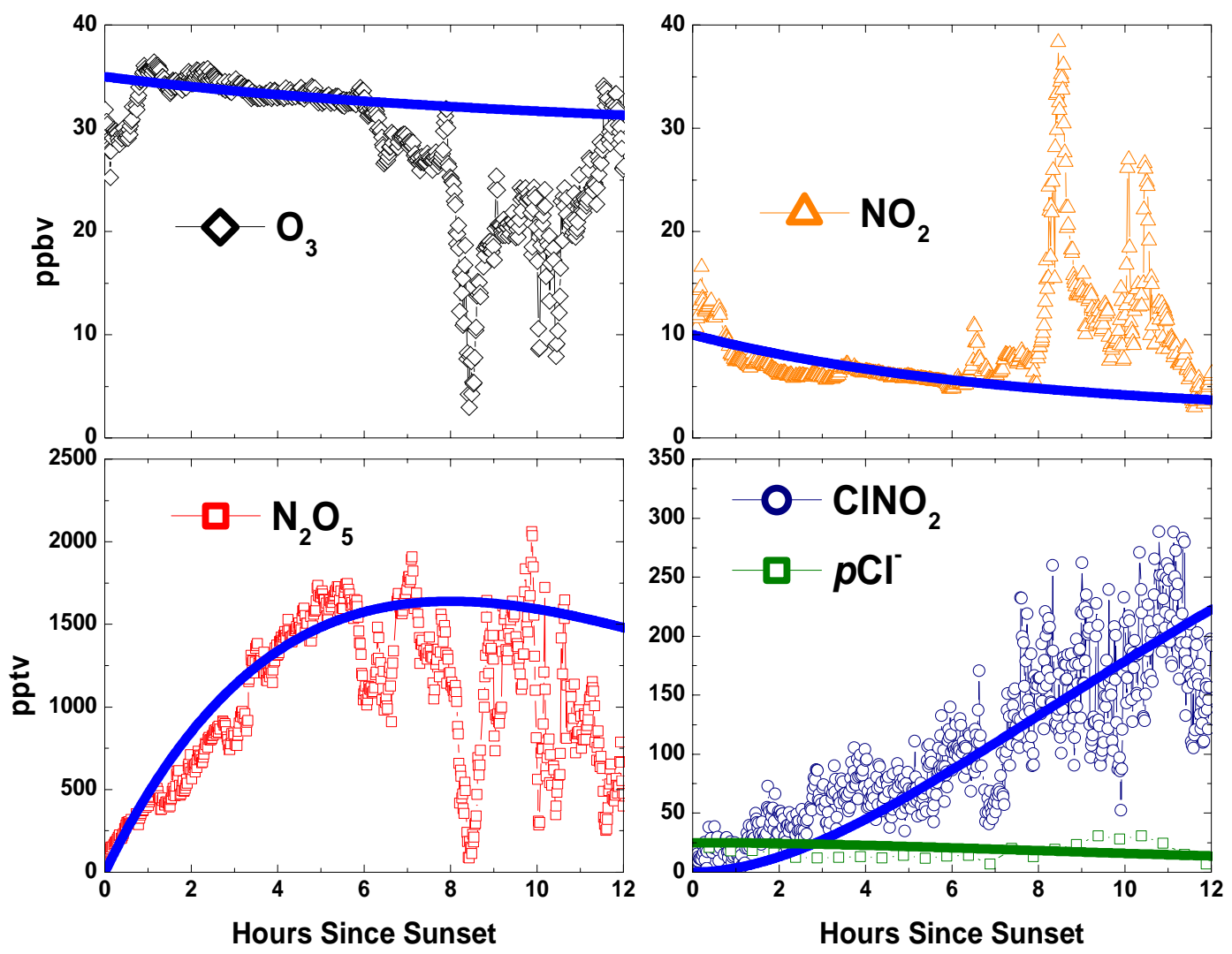

Supplementary Figure 5: Observations and box model results for the night of February 22$23^{\text {rd }}$. Observations of ozone (top left), $\mathrm{NO}_{2}$ (top right), $\mathrm{N}_{2} \mathrm{O}_{5}$ (bottom left), $\mathrm{ClNO}_{2}$ and $p \mathrm{Cl}^{-}$ (bottom right, circles and squares, respectively) are shown as symbols connected by thin lines, model predictions are as a thick blue line with the exception of that for $\mathrm{pCl}^{-}$(thick green line). 


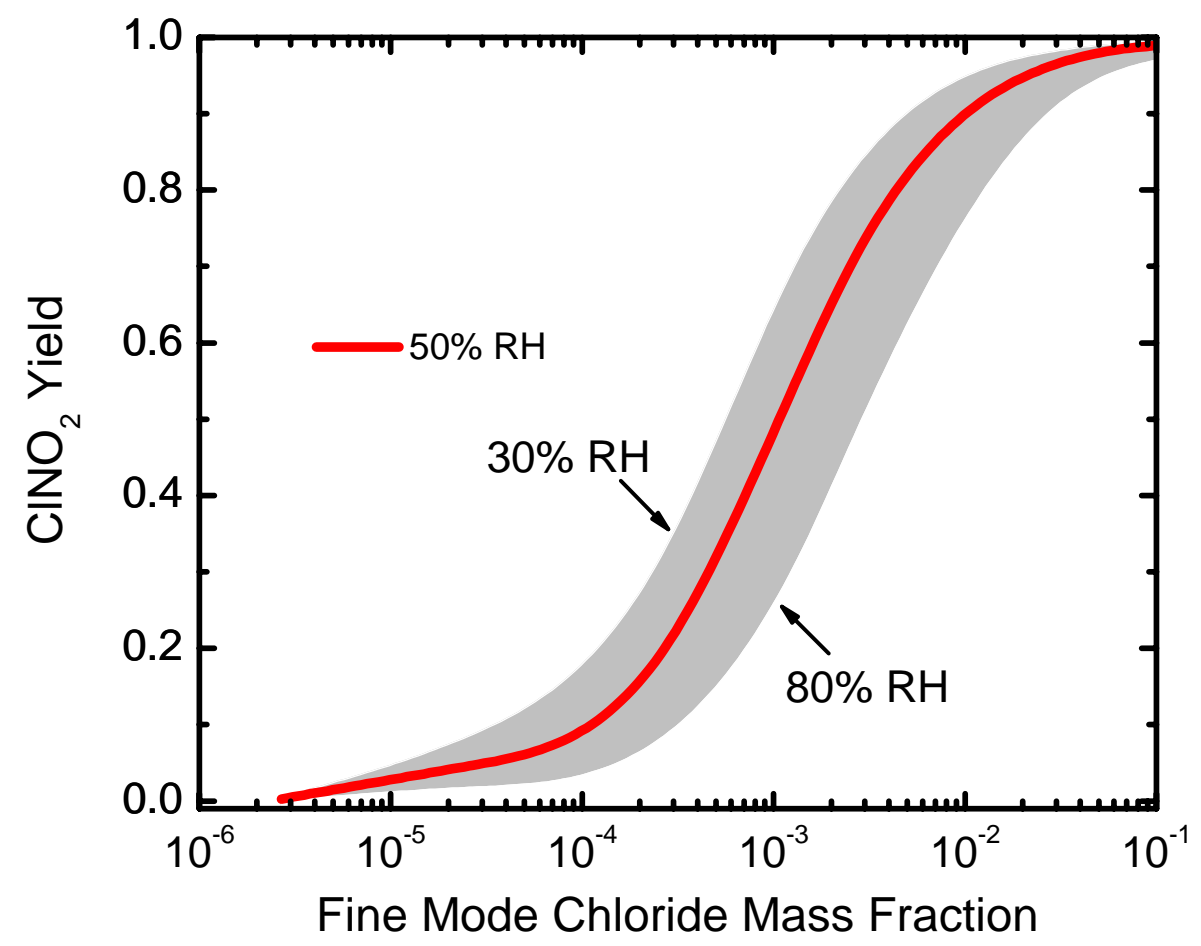

Supplementary Figure 6: $\mathrm{CINO}_{2}$ yield from reaction $\mathrm{R} 1$ versus particulate chloride mass fraction. The yields were calculated from a combination of thermodynamic output from the Aerosol Inorganics Model (AIM) and kinetic data. ${ }^{32}$ The grey area corresponds to the changes due to varying relative humidity. 

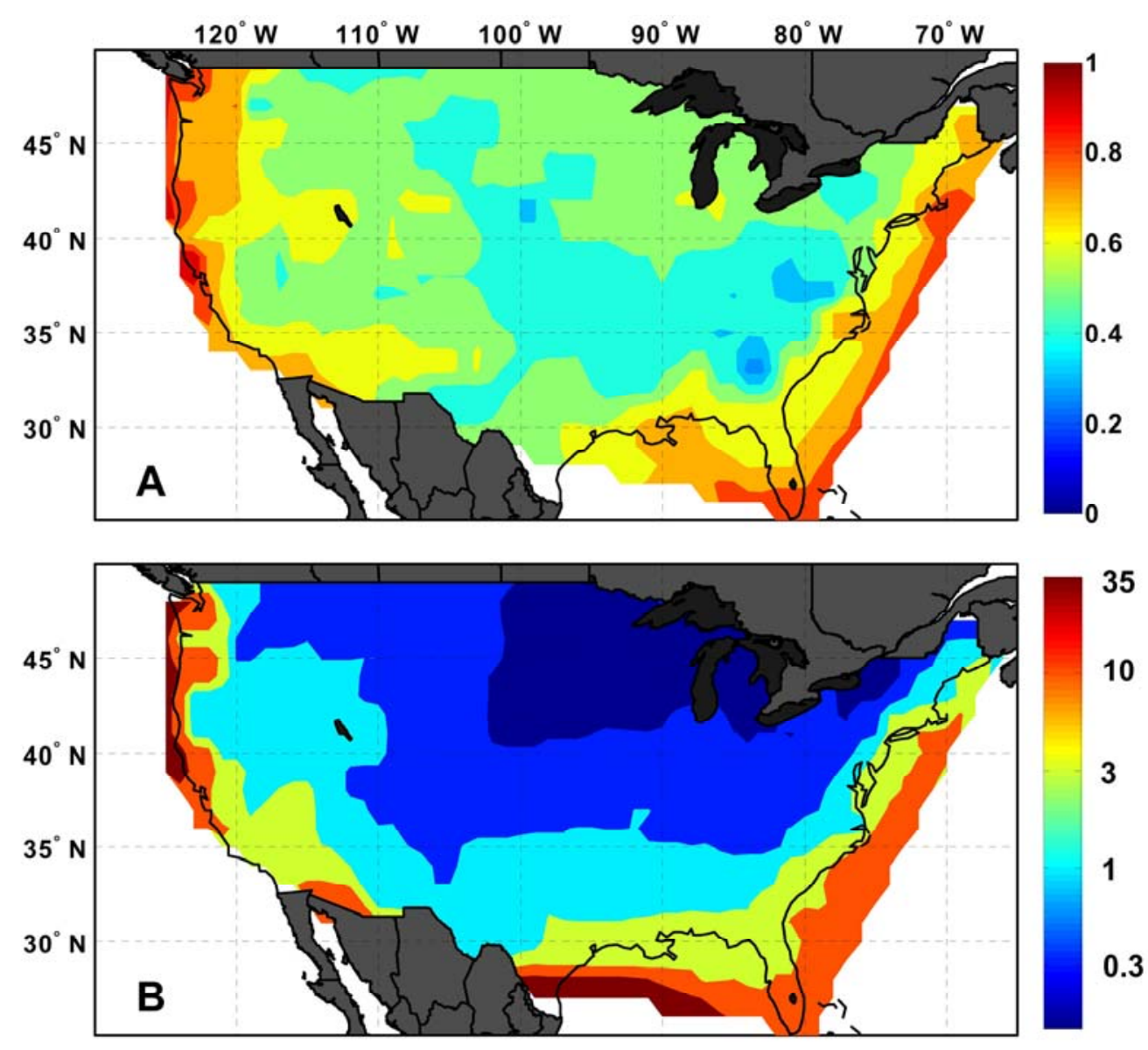

Supplementary Figure 7: Estimated annual average branching between reactions R1a and

R1b and chloride availability. In panel $\mathbf{A}$, the annual mean $\phi_{\mathrm{CINO}_{2}}^{\mathrm{IMP}}$, derived from the IMPROVE chloride fine mode mass fraction, equation SE3, and an assumption of $80 \% \mathrm{RH}$ is shown. In panel $\mathbf{B}$, the annual mean $\phi_{\mathrm{ClNO}_{2}}^{\mathrm{NADP}}$ is shown, as derived from the chloride and nitrate measured in precipitation by the NADP and equation SE4. Note that the color scales are different for the two panels. 

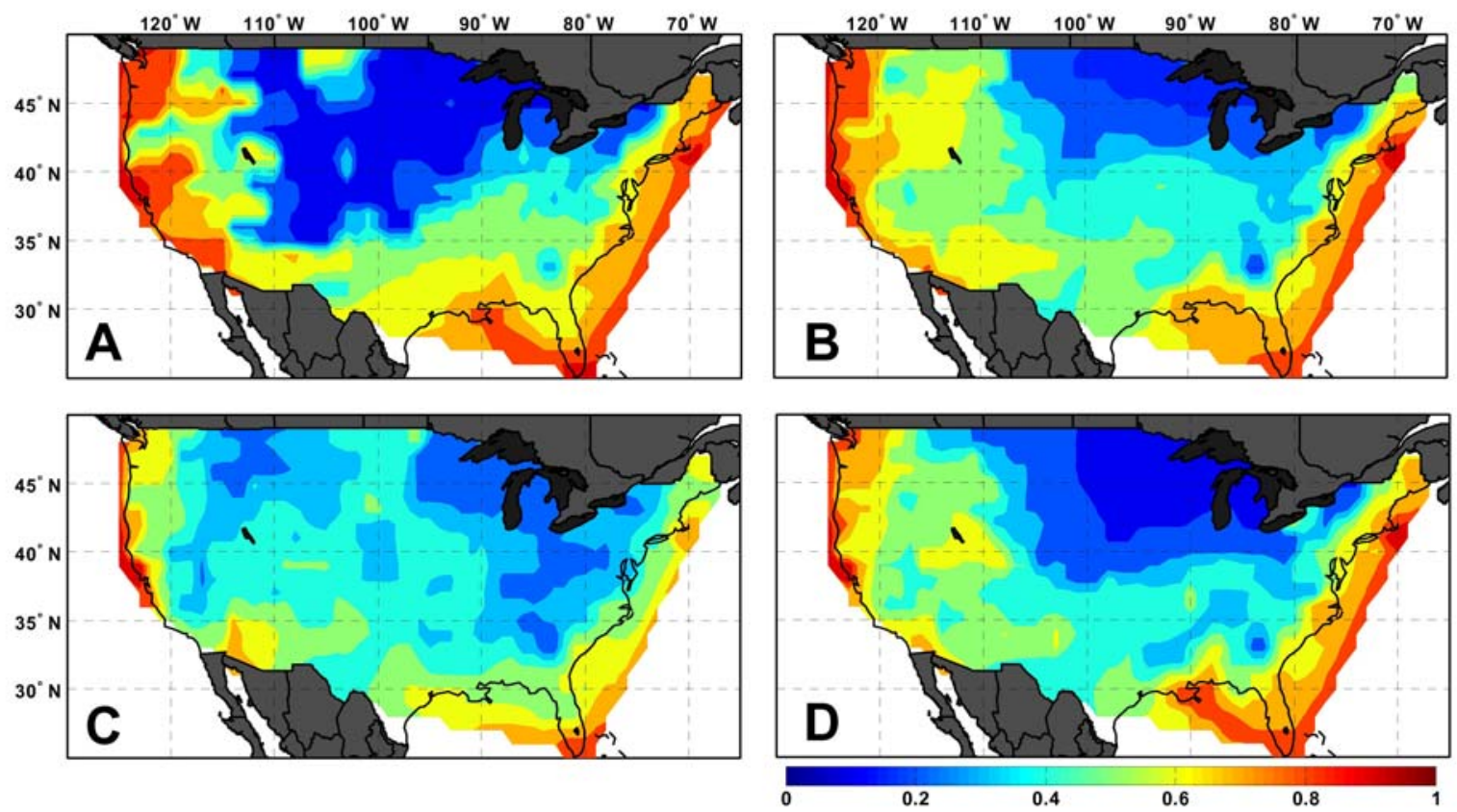

Supplementary Figure 8: Seasonal yields of $\mathrm{CINO}_{2}$ estimated from a IMPROVE and NADP

data. Values of $\phi_{\mathrm{CINO} 2}$ are derived from the lesser of the two values of $\phi_{\mathrm{CINO}_{2}}^{\mathrm{IMP}}$ or $\phi_{\mathrm{CINO}_{2}}^{\mathrm{NADP}}$ in each

grid cell, and are shown for winter (A), spring (B), summer (C), and fall (D). See text for details. 

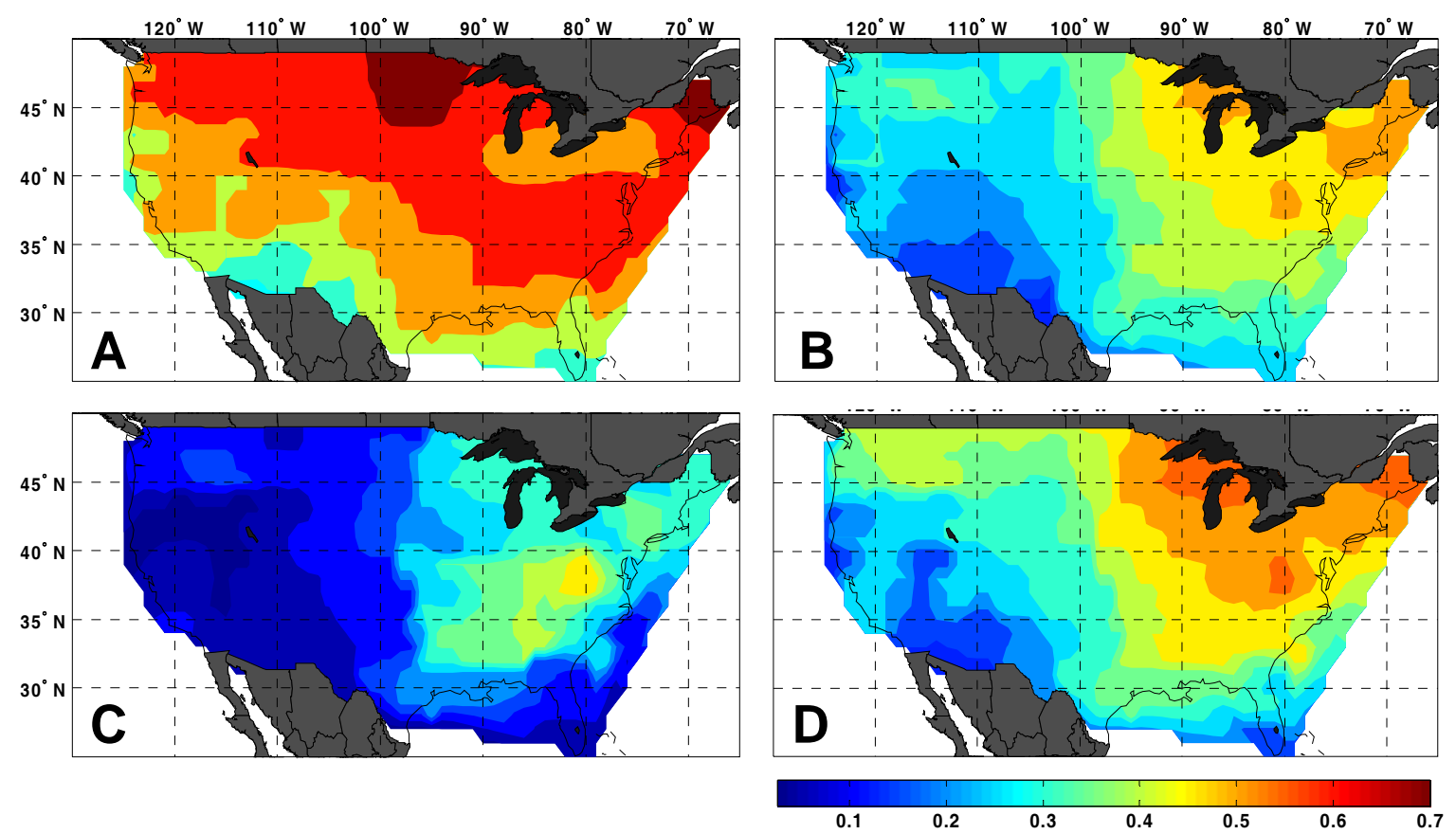

Supplementary Figure 9: Fraction of nitrate produced from $\mathrm{N}_{2} \mathrm{O}_{5}$ heterogeneous chemistry. Values of $f_{N 2 O 5}$ are predicted by the GEOS-Chem model, integrated over the first 2 $\mathrm{km}$ in altitude and averaged over winter (A), spring (B), summer (C), and fall (D). 

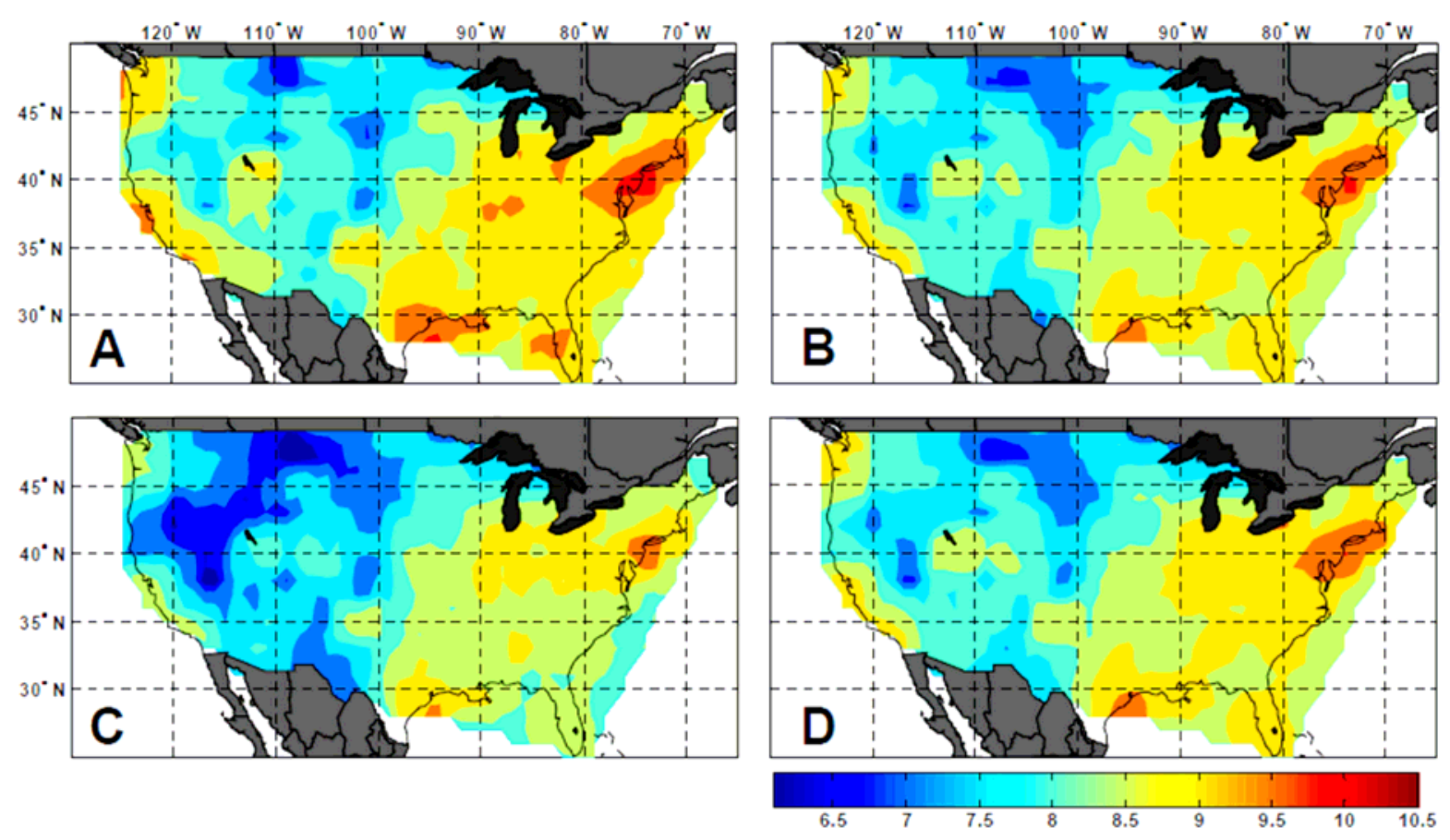

Supplementary Figure 10: Seasonal $\mathrm{CINO}_{2}$ production rates over the continental U.S. The color scale is logarithmic, in units of $\mathrm{g} \mathrm{Cl}$ season $^{-1}$ with a minimum value of $10^{6.5} \mathrm{~g} \mathrm{Cl}$ season ${ }^{-1}$ and is the same for winter (A), spring (B), summer (C), and fall (D) values. The color scale is meant to illustrate the relative importance of coastal versus continental production. The corresponding spatially integrated production rates are given in the text. 


\section{Supplementary Tables}

Supplementary Table 1. Key Chemical reactions used in 0-D box model

\begin{tabular}{ll}
\hline & Reaction \\
\hline $\mathrm{SR} 2$ & $\mathrm{NO}+\mathrm{O}_{3} \rightarrow \mathrm{NO}_{2}+\mathrm{O}_{2}$ \\
$\mathrm{SR} 3$ & $\mathrm{NO}_{2}+\mathrm{O}_{3} \rightarrow \mathrm{NO}_{3}+\mathrm{O}_{2}$ \\
$\mathrm{SR} 4$ & $\mathrm{NO}_{3}+\mathrm{NO}_{2} \rightleftarrows \mathrm{N}_{2} \mathrm{O}_{5}$ \\
$\mathrm{SR} 5$ & $\mathrm{NO}_{3} \rightarrow$ Products \\
R1a & $\mathrm{N}_{2} \mathrm{O}_{5}+$ particles $\rightarrow 2 \mathrm{HNO}_{3}$ \\
R1b & $\mathrm{N}_{2} \mathrm{O}_{5}+$ particles $\rightarrow \mathrm{ClNO}_{2}+\mathrm{HNO}_{3}$ \\
\hline
\end{tabular}

